\title{
Lactic Acid Fermentation of Arabinoxylan From Nejayote by Streptococcus infantarius ssp. infantarius 25124 Isolated From Pozol
}

\begin{abstract}
Barbara Cooper-Bribiesca ${ }^{1}$, Arturo Navarro-Ocaña ${ }^{1}$, Gloria Díaz-Ruiz' Guillermo Aguilar-Osorio', Romina Rodríguez-Sanoja ${ }^{2}$ and Carmen Wacher ${ }^{1 *}$

${ }^{1}$ Departamento de Alimentos y Biotecnología, Facultad de Química, Universidad Nacional Autónoma de México, Mexico City, Mexico, ${ }^{2}$ Instituto de Investigaciones Biomédicas, Universidad Nacional Autónoma de México, Mexico City, Mexico
\end{abstract}

Streptococcus infantarius ssp. infantarius 25124 (Sii-25124) is a lactic acid bacterium $(\llcorner A B)$ isolated from pozol, a refreshing beverage prepared by suspending fermented nixtamal (a thermal and alkali-treated maize dough) in water. Although Lactobacillus are the predominant strains in fermented doughs, such as sourdoughs, and nonnixtamalized fermented maize foods, the pozol microbiota is markedly different. This may be the result of the nixtamalization process, which could act as a selective force of some strains. Sii-25124 has been reported as the main amylolytic LAB in pozol; starch is the primary carbon source on nixtamal since monosaccharides and disaccharides are lost during nixtamalization; however, non-amylolytic LAB counts are higher than amylolytic $L A B$ in pozol after 24-h fermentation suggesting that another carbon source is being used by the former bacteria. Hemicellulose (arabinoxylan in maize) becomes available via nixtamalization and is subsequently metabolized by $L A B$. The aim of this work was to determine whether this bacterium is able to use arabinoxylan as the only carbon source in a defined medium containing arabinoxylan extracted from either nejayote (wash water produced during nixtamal preparation), or beechwood xylan. Xylanase activity in the presence of nejayote arabinoxylan (135.8 $\pm 48.7 \mathrm{IU} / \mathrm{mg}$ protein) was higher than that of beechwood ( $62.5 \pm 19.8 \mathrm{IU} / \mathrm{mg}$ protein). Other enzymatic activities, such as arabinofuranosidase and acetyl esterase, were also detected, suggesting the adaptation of the bacterium studied to nixtamal dough. It was concluded that Streptococcus infantarius 25124 isolated from pozol was able to use arabinoxylans, which are present in nixtamal dough, so fermentation does not depend exclusively on free sugars and starch.

Keywords: Streptococcus infantarius ssp. infantarius, lactic acid bacteria, arabinoxylan, pozol, nixtamal

\section{INTRODUCTION}

Pozol is one of the most important traditional pre-Columbian non-alcoholic beverages in southeastern Mexico, where it is consumed as part of the daily diet. It is made of fermented nixtamal (heat- and alkali-treated maize dough). To prepare pozol, maize is nixtamalized; to this end, white, yellow or mestizo corn is shelled and kernels are cooked with lime (0.6-1.2\% dry maize weight) for 
50-80 min, followed by a 12 - to 14 -h soaking in its own cooking liquor. Afterward, the product is washed with water two to three times and rubbed by hand to remove the pericarp and lime, and is then coarsely ground (Ulloa et al., 1987; Cañas et al., 1993). The resulting heterogeneous dough, also known as masa or nixtamalized masa, is shaped into balls, wrapped in banana leaves, and allowed to ferment for a period of time that varies from approximately $3 \mathrm{~h}$ up to 1 month or longer. A complex microbiota is found in the fermenting dough; the microbial ecology of pozol has been studied by Ampe et al. (1999), Ben Omar and Ampe (2000), Escalante et al. (2001), and Díaz-Ruiz et al. (2003). They found a variable diversity of species, which after $24 \mathrm{~h}$ of fermentation are reduced to strains belonging mainly to the genera Streptococcus, Weissella, Enterococcus, and Lactococcus. Streptococcus infantarius ssp. infantarius 25124 (Sii-25124) is the main amylolytic LAB (ALAB) of pozol. Streptococcus infantarius ssp. infantarius strains have also been isolated from traditional fermented dairy products for example maasai fermented milk and Fènè (fermented cow milk) (Jans et al., 2017). It has been reported as pathogenic and there is not yet a general method to discriminate pathogenic from nonpathogenic strains. Kaindi et al. (2018) isolated bacteria of the same subspecies from African dairy products, which were clearly different from the human strain Streptococcus infantarius ssp. infantarius. Coming from a fermented food, it is possible that our Sii-25124 is also different from human strains. Streptococcus infantarius ssp. infantarius (Sii) was previously classified as Streptococcus bovis biotype II/1, but it was differentiated through phenotypic and genotypic Schlegel et al. (2000, 2003) and sodA gene sequencing (Poyart et al., 2002; Romero et al., 2011). Members of the Streptococcus bovis/Streptococcus equinus, to which Streptococcus infantarius ssp. infantarius 25124 (Sii-25124) belongs, have been reported as pathogenic, associated mainly with colorectal cancer; however, it is also known that there are safe strains. The problem of detecting the pathogenic strains is presently a topic of arduous study (Papadimitriou et al., 2014; Jans and Bolieij, 2018). Compared to other ALAB, it shows a low amylolytic activity (130.7 U/g dry cell weight/h in MRS starch (De Man RogosaSharp medium), but a high specific growth rate ( $\mu=0.94 / \mathrm{h}$ ); compared to Lactobacillus fermentum shows an amylolytic activity of $1,890 \mathrm{U} / \mathrm{g}$ dry cell weight/h in MRS starch and a specific growth rate of $0.35 /$ h (Díaz-Ruiz et al., 2003).

During nixtamalization, a large proportion of soluble carbohydrates are removed. Sucrose concentration is reduced to 100-700 mg/100 g dry dough (Santillana, 1995), and maltose and glucose have each been detected at concentrations below $3.6 \mathrm{mg} / 100 \mathrm{~g}$ in dry dough (Ben Omar and Ampe, 2000); thus, starch is left as the main carbohydrate for microbial growth. However, maize pericarp contains hemicellulose and cellulose, both of which are structural carbohydrates, and nixtamal dough contains $6 \%$ total non-starch polysaccharides (NSP), by dry weight (Englyst and Hudson, 1996; Instituto Nacional de Nutrición Salvador Zubirán [INNSZ], 1996; Sanchez-Castillo et al., 1999).

Nejayote is the wastewater (wash water) resulting from nixtamalization. It is highly alkaline $(\mathrm{pH} 11-12)$ and contains more than $60 \%$ of alkali-soluble NSP from maize pericarp, which are mainly arabinoxylans. The information currently available on xylanase activity by LAB is scarce. Moreover, efforts to identify xylanolytic activity have detected that even in the presence of the $x y l$ operon, the dairy starter culture strain Lactococcus lactis 210 displays a loss of function of the xylanase genes. In addition, while plant environmental isolates such as L. lactis NRRL B4449 and $L$. lactis IO-1 retain the ability to metabolize xylose, neither of these two strains is able to grow in the presence of xylan or xylobiose (Erlandson et al., 2001). Only putative xylan-acting enzymes in Streptococcus, Lactococcus, Lactobacillus, and Enterococcus, and at least two in Tetragenococcus and one in Leuconostoc, have been found in databases (Uniprot, 2015); however, no functional xylanases from LAB have been reported.

Besides their importance as carbon and energy sources, xylan hydrolysis products may include xylooligosaccharides (XOs), which are considered to be prebiotics: wheat-bran XOs are utilized by Bifidobacteria, Lactobacilli, and Pediococci spp., as reported by Madhukumar and Muralikrishna (2012).

Because of the lack of monosaccharides and disaccharides in nixtamal, starch has been considered to be the main carbohydrate used by LAB during pozol fermentation. However, non-amylolytic LAB outgrow ALAB during pozol fermentation (Díaz-Ruiz et al., 2003), suggesting that another carbon source is being used by the former bacteria. During nixtamalization, the structural carbohydrates of maize, particularly hemicelluloses, should become more accessible for xylanolytic LAB due to their solubility in alkaline water.

There is little information regarding hemicellulose hydrolysis by LAB. The purpose of this work was to determine whether Streptococcus infantarius ssp. infantarius 25124 (Sii-25124) is able to use either maize arabinoxylan or beechwood xylan as carbon source, and whether it possesses the functional enzymes needed to hydrolyze both polysaccharides. We also aimed to characterize the fermentation of maize arabinoxylan extracted from nejayote by Streptococcus infantarius ssp. infantarius 25124 (Sii-25124).

\section{MATERIALS AND METHODS}

\section{Microorganisms and Culture Conditions}

Streptococcus infantarius ssp. infantarius 25124 (Sii-25124) isolated from pozol was recovered from cryo freezer vials containing glycerol, $50 \mu \mathrm{l}$ in $5 \mathrm{~mL}$ APT broth (BD-DIFCO, United States) and incubated at $30^{\circ} \mathrm{C}$ for $24 \mathrm{~h}$. A $10 \%$ (v/v) aliquot was then transferred to an 18 -mL screw cap tube containing MRS broth prepared with $1 \%(\mathrm{w} / \mathrm{v})$ beechwood xylan (Sigma-Aldrich, United States, 90\% purity) instead of glucose (MRS-X). Samples were then incubated at $30^{\circ} \mathrm{C}$ for $18 \mathrm{~h}$.

\section{Semiquantitative Xylanase Activity}

The culture described above was used to streak MRS-Xylan (MRS-X) plates and incubated for 3 days at $28^{\circ} \mathrm{C}$. Afterward, plates were flooded with Gram's iodine and xylanase activity was determined semi-quantitatively based on the size of clear halos around colonies. Cellulomonas flavigena CDBB531 (Pérez-Avalos et al., 1996) was used as positive control. 


\section{Arabinoxylan Extraction From Nejayote Liquor}

Maize arabinoxylan was obtained from nejayote using a modification of the procedure described by Carvajal-Millan et al. (2007). Nejayote was sampled from a commercial mill located at the Niños Heroes market in Mexico City. Fifty kilograms of maize kernels were boiled in $1 \%(\mathrm{w} / \mathrm{v})$ lime for $1 \mathrm{~h}$, then left to stand for $12 \mathrm{~h}$. Afterward, the liquid (nejayote) was drained out and maize kernels were processed to obtain the dough. Nejayote was recovered and filtered using a cloth, then centrifuged at $10,000 \mathrm{rpm}$ and $20^{\circ} \mathrm{C}$ for $15 \mathrm{~min}$ to remove particles; the $\mathrm{pH}$ of the supernatant was adjusted to 5 with $3 \mathrm{~N} \mathrm{HCl}$, and absolute ethanol was added with gentle stirring to a final concentration of $65 \%(\mathrm{v} / \mathrm{v})$. Afterward, samples were incubated overnight at $4^{\circ} \mathrm{C}$. The precipitated polymer was filtered and dried by adding 0.5 volumes of ethanol and 0.25 volumes of acetone per volume of filtrated nejayote. The dry residue was then dissolved in a minimum volume of hot distilled water and freeze-dried. Fourier Transform Infrared Spectroscopy (FIT-IR) was performed by the Analytical Services Unit at Faculty of Chemistry, UNAM, on dry samples of the arabinoxylan extracted, to confirm the nature of this chemical.

\section{Growth Kinetics on Beechwood Xylan and Nejayote Arabinoxylan}

One-hundred-milliliter flasks containing $45 \mathrm{~mL}$ of HSH-defined medium broth (Owens and Keddie, 1969; Nuraida et al., 1992; Westby et al., 1993; Zaunmüller et al., 2006) were prepared with either $1 \%(\mathrm{w} / \mathrm{v})$ beechwood xylan (Sigma-Aldrich, United States) or $1 \%(\mathrm{w} / \mathrm{v})$ nejayote arabinoxylan, each inoculated with $5 \mathrm{~mL}$ of the prepared inoculum and incubated without stirring at $28^{\circ} \mathrm{C}$. Aliquots were collected at 3 -h intervals from baseline to $12 \mathrm{~h}$, then at $24 \mathrm{~h}$ at $48 \mathrm{~h}$, to evaluate growth. In each time point, aliquots were centrifuged $(10,000 \mathrm{rpm}, 5 \mathrm{~min})$ and the supernatant was used to measure sugar concentration and enzymatic activities. Each sample was collected after stirring, since nejayote arabinoxylan is not completely solubilized.

\section{Growth Evaluation}

Growth of the strain studied was evaluated by plate count on MRS agar (BD-DIFCO, United States), incubating for $24 \mathrm{~h}$ at $30^{\circ} \mathrm{C}$, and the results were reported as $\log \mathrm{CFU} / \mathrm{mL}$. Data were obtained from biological triplicates. The specific growth rate was determined from a regression analysis of the experimental data with the Logistic and Gompertz models (Zwietering et al., 1990; Baty and Delignette-Muller, 2004).

\section{Total and Reducing Carbohydrates}

Reducing sugars were analyzed by the dinitrosalicylic acid (DNS) method (Miller, 1959) using a xylose standard curve (0.025-0.6 mg/mL, Sigma-Aldrich, United States). Properly diluted supernatants were tested for total sugar content by the phenol sulfuric acid method as described by Dubois et al. (1956) and expressed as xylose equivalents; sugar content was calculated using a calibration curve spanning from $0.01 \mathrm{mg} / \mathrm{mL}$ to $0.1 \mathrm{mg} / \mathrm{mL}$ xylose.

\section{Fermentation Metabolites}

The HPLC parameters were as follows: Waters AF equipment, Waters binary pump 1525, Waters Autosampler 2707, Waters dual Absorbance detector 2487, Empower software, and AminexHPX-87H column $(300 \mathrm{~mm} \times 7.8 \mathrm{~mm})$. The mobile phase was $0.05 \mathrm{~N} \mathrm{H}_{2} \mathrm{SO}_{4}$. The flow rate was $0.6 \mathrm{~mL} / \mathrm{min}$ with a $30-\mu \mathrm{L}$ injection volume and a working temperature of $30^{\circ} \mathrm{C}$. A UV detector was used for the fermentation products (lactic and acetic acids, ethanol). Each compound was identified by comparing its retention time vs. standards (Sigma-Aldrich, United States). Concentrations were calculated by comparing peak areas against calibration curves prepared separately as follows: ethanol, $0.2-1 \%(\mathrm{v} / \mathrm{v})$; lactic acid, $0.2-1.2 \mathrm{mg} / \mathrm{mL}$; acetic acid, $0.012-0.0042 \mathrm{mg} / \mathrm{mL}$.

\section{Xylanase Activity Overall Xylanase Activity}

Xylanase activity was measured according to Rickard and Laughlin (1980) using 1\% (w/v) beechwood xylan as substrate. A xylanolitic bacterium, Cellulomonas flavigena CDBB531 (Pérez-Avalos et al., 1996), was used as positive control. Activity was determined by measuring the increase in reducing sugars released during a 20 -min incubation at $40^{\circ} \mathrm{C}$ in a solution containing $500 \mu \mathrm{l}$ supernatant, $500 \mu \mathrm{l}$ citrate-phosphate buffer $(\mathrm{pH}$ 6.8) and $500 \mu \mathrm{l}$ beechwood xylan (1\% w/v) in distilled water (Bailey et al., 1992). The reaction was stopped by adding $1.5 \mathrm{~mL}$ of DNS, then shaking and boiling the samples for 5 min. Reducing sugars were measured by spectrophotometry (Spectronic 21D, Milton Roy, United States) at $540 \mathrm{~nm}$ using a xylose standard (Sigma-Aldrich, United States) (Miller, 1959) and a calibration curve ranging from $0.025 \mathrm{mg} / \mathrm{mL}$ to $0.6 \mathrm{mg} / \mathrm{mL}$. Protein concentration was determined according to the method of Bradford (1976) using bovine serum albumin as reference standard. One international unit (IU) of activity was defined as $1 \mu \mathrm{mol}$ of xylose or xylose equivalents released per minute under the assay conditions described. All tests were carried out in triplicate, and average values were recorded.

\section{$\beta$-Xylosidase Activity}

The activity of $\beta$-xylosidase was determined by incubating $25 \mu \mathrm{L}$ of the fermentation supernatant with $100 \mu \mathrm{L}$ of $1 \mathrm{mg} / \mathrm{mL}$ p-nitrophenyl-D-xylopyranoside (PNP-xyl, SigmaAldrich, United States) in citrate-phosphate buffer $(0.1 \mathrm{M}$ and $0.2 \mathrm{M}$, respectively) ( $\mathrm{pH} 6.8$ ) at $40^{\circ} \mathrm{C}$ for $20 \mathrm{~min}$. The reaction was stopped by adding $75 \mu \mathrm{L}$ of $0.25 \mathrm{M} \mathrm{Na}_{2} \mathrm{CO}_{3}$, and the p-nitrophenol released was measured using a spectrophotometer (Spectronic 21D, Milton Roy, United States) at $405 \mathrm{~nm}$, reagent and substrate blanks were employed. One unit of $\beta$-D-xylosidase activity was defined as the amount of enzyme that released $1 \mu \mathrm{mol}$ of $p$-nitrophenol per milliliter under the assay conditions.

\section{Supplementary Xylanase Enzymes}

Additional enzymatic activities were assayed with the appropriate PNP substrates, all of which were sourced from Sigma-Aldrich, United States ( $\mathrm{pNP}-\beta$-D-glucopyranoside; $\mathrm{pNP}$ $\alpha$-D-glucopyranoside; $\mathrm{pNP}-\beta$-arabinofuranoside, $\mathrm{pNP}-\alpha$-arabi nofuranoside; $\mathrm{pNP}-\beta$-D-galactopyranoside, $\mathrm{pNP}-\alpha$-D-galacto 
pyranoside, pNP- $\alpha$-xylopyranoside, and pNP-4-nitrophenylacetate), using the same conditions as described for $\beta$-xylosidase activity.

\section{Statistical Analysis}

The differences between the xylan and arabinoxylan fermentations were assessed through the differences between the areas under the curve and comparing the differences between the average values with a Student's $t$-distribution $(\alpha=0.01)$.

\section{RESULTS}

\section{Nature of the Chemical Extracted From Nejayote}

Arabinoxylan from nixtamal was used as the substrate to assess whether Sii-25124 was able to use it as the only carbon source. It is soluble in alkali, so it is found in the dough and also at high concentrations in nejayote, i.e., the nixtamalization wash water. The FIT-IR spectrum of the chemical extracted from nejayote showed the typical signals of hemicelluloses: a strong signal at
$3316.41 / \mathrm{cm}$ from -OH stretching; at $1147 / \mathrm{cm}$ from C-O and C-O$\mathrm{C}$ stretching and $\mathrm{C}-\mathrm{OH}$ bending of arabinoxylan-hemicelluloses; at $1022 / \mathrm{cm}$ from $\mathrm{C}-\mathrm{OH}$ bending of hemicelluloses; and at $860 / \mathrm{cm}$ from $\beta$-glucoside bonds in hemicellulose and a furanoid ring (arabinofuranoside) (Figure 1). The typical signals of absorbed water, protein or lignin were not detected at the 1700-1500 and 1654-1539 regions. The spectrum resembled the one obtained by Oliveira et al. (2010) for corncob arabinoxylan. This product showed only one signal on HPLC and was assayed for reducing sugars with only $7.71 \mu \mathrm{g}$ per mg arabinoxylan; therefore, it contains no other free sugars and can be used to assess its consumption.

\section{Growth of Sii-25124 on Beechwood Xylan and Nejayote Arabinoxylan in HSH Broth}

Sii-25124 was able to grow in both xylan types. Significant differences were observed in growth; reducing and total sugar consumption rates; and enzymatic activity induced by xylan and arabinoxylan. No lag phase was observed in arabinoxylan; in contrast, for beechwood xylan the log phase started after $3 \mathrm{~h}$ (Figure 2A). The logistic model resulted in the better goodness

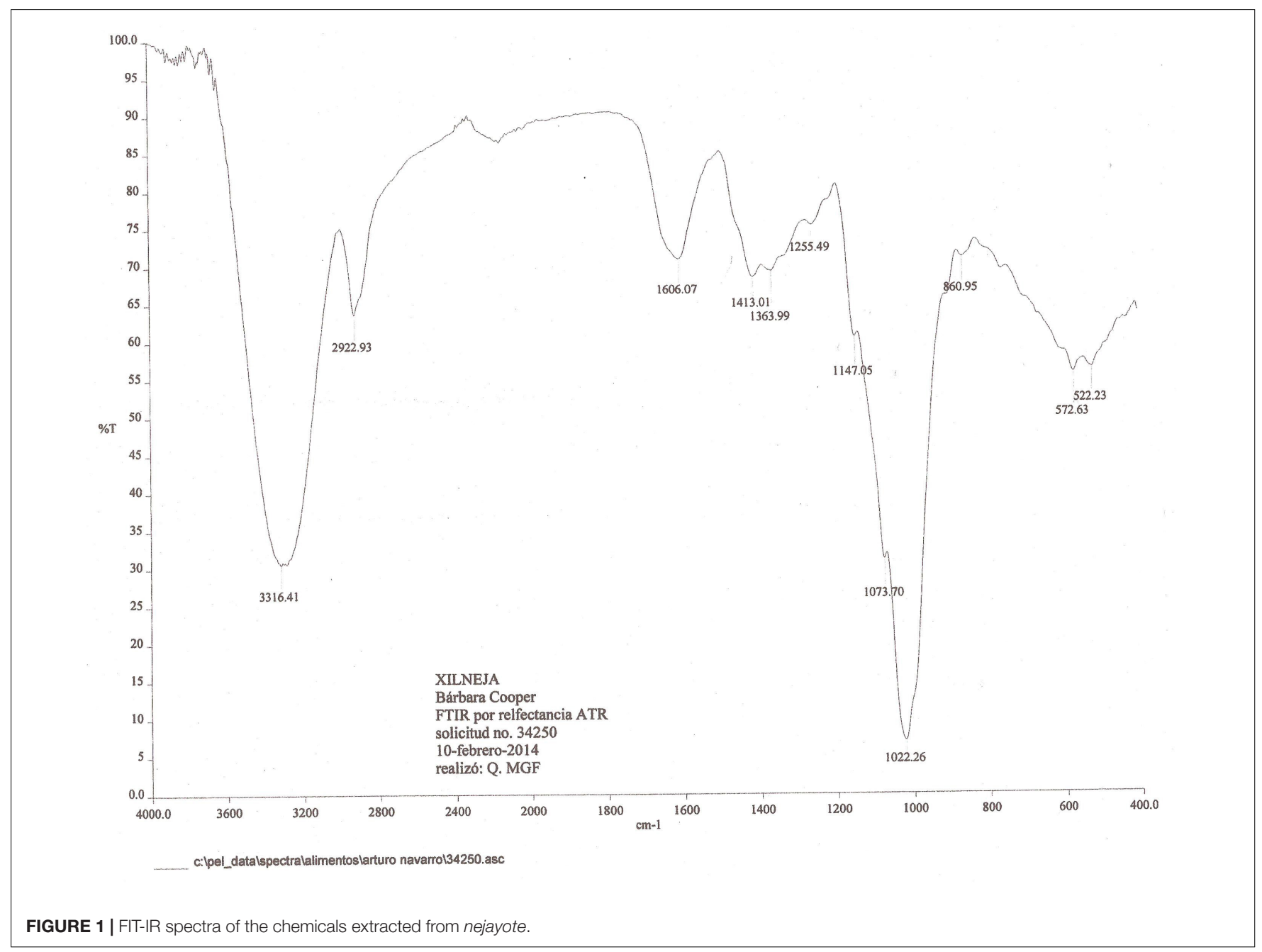



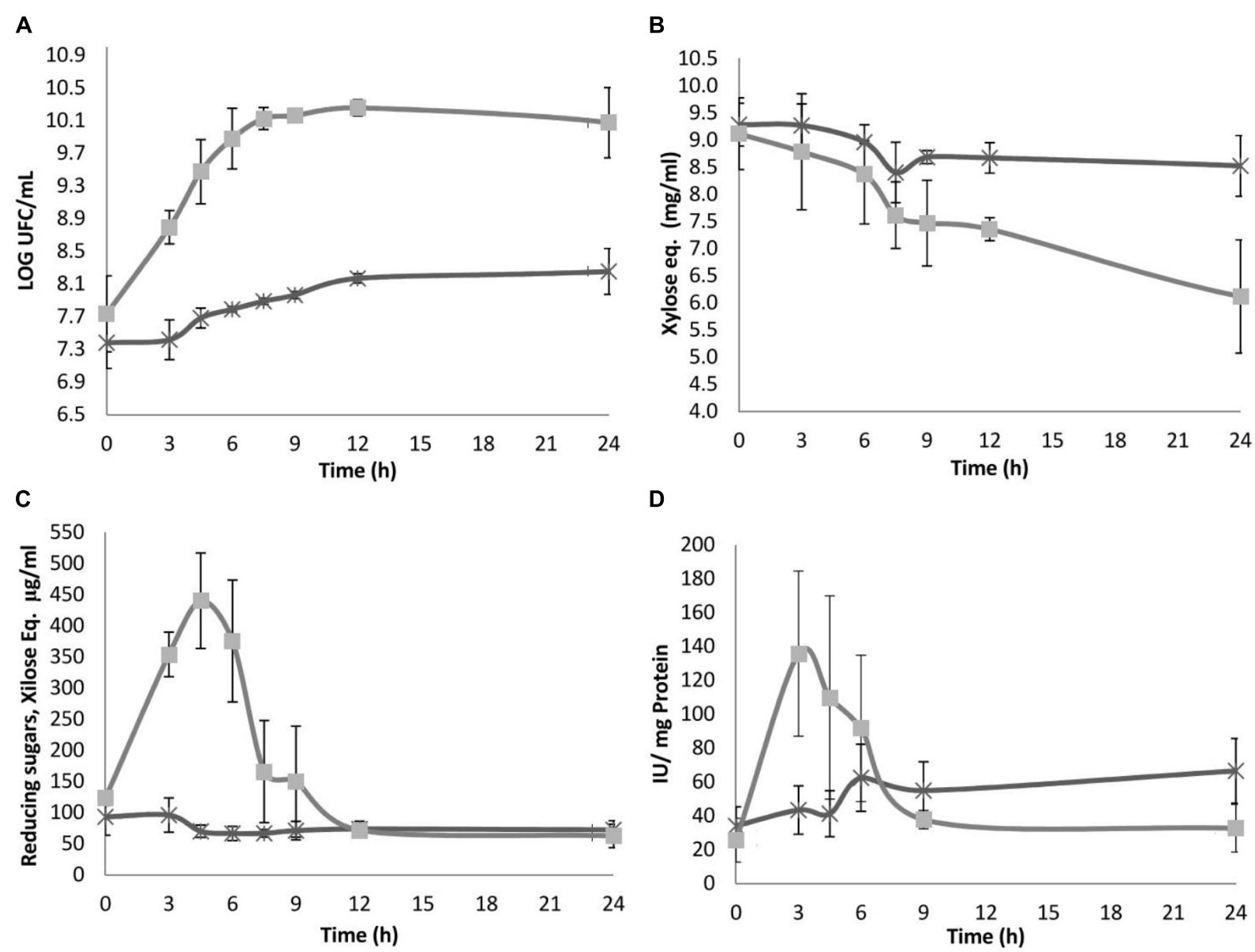

D

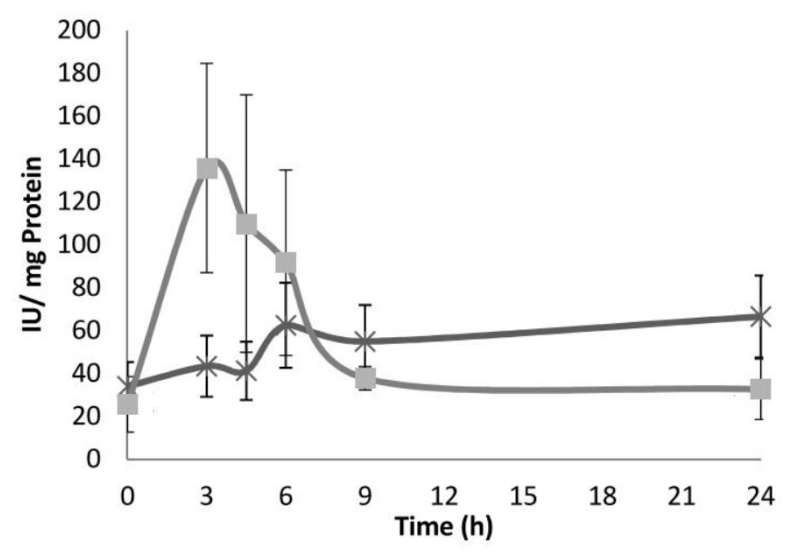

FIGURE 2 | (A) Growth, (B) total carbohydrates, (C) reducing sugars, and (D) specific xylanase activity; concentration during fermentation by Streptococcus infantarius ssp. infantarius 25124 in HSH broth spiked with $1 \%$ beech wood xylan $(X)$ and nejayote arabinoxylan $(\square)$ as carbon sources. Results are means of three separate fermentations; standard deviations are shown as vertical lines. There were statistically significant differences between the treatments (nejayote arabinoxylan vs. beechwood xylan) ( $\alpha=0.01)$.

of fit than the Gompertz model for both microorganisms. The criterion to differentiate between both models was the sum of squared residuals, expressed as $\operatorname{SSR}=\sum_{i=1}^{n}(y \text { pred }-y \exp )_{i}^{2}$, where $y$ pred and $y$ exp are the predicted and experimental values of microbial growth, respectively. Thus, the values of $\mu$ max were $0.109 \mathrm{~h}^{-1}\left(\mathrm{SSR}=3.183 \cdot 10^{-3}, r^{2}=0.9683\right)$ for arabinoxylan, and $0.0267 \mathrm{~h}^{-1}\left(\mathrm{SSR}=9.548 \cdot 10^{-4}, r^{2}=0.9551\right)$ for beechwood xylan.

On HSH beechwood xylan, Sii-25124 population increased one log unit after $48 \mathrm{~h}$. Sii-25124 grown in nejayote arabinoxylan displayed a growth rate four times as high as in beechwood xylan and reached the stationary phase after $12 \mathrm{~h}$ (with a population increase of nearly $3 \log$ units in $12 \mathrm{~h}$ ). After $24 \mathrm{~h}$, the culture containing nejayote arabinoxylan entered the death phase concurrent with a decrease in the population vs. cultures grown in beechwood xylan, which showed a continuous linear growth (Figure 2A). The strain was able to grow in HSHglucose and $\mathrm{HSH}$-xylan, but not in HSH medium with no carbon source (data not shown), hence demonstrating that growth on arabinoxylan results from the use of this carbon source. The $\mathrm{pH}$ of both cultures remained constant at 6.8 , likely because the HSH medium contained phosphate buffer $\mathrm{pH} 6.8$.

\section{Total Carbohydrates}

Samples grown in nejayote arabinoxylan displayed a rapid decrease in total carbohydrate concentration, from 9.11 to $5.10 \mathrm{mg} / \mathrm{mL}$ (56\% consumption), after $24 \mathrm{~h}$. Samples grown in beechwood xylan showed a decrease in total carbohydrate concentration (from 9.28 to $7.87 \mathrm{mg} / \mathrm{mL} ; 15 \%$ ) after $24 \mathrm{~h}$ (Figure 2B). These results suggest a lower consumption of beechwood xylan vs. nejayote arabinoxylan, reflected as a lower growth rate in the culture medium (Figure 2A).

\section{Reducing Carbohydrates}

Reducing carbohydrates were measured to account for the production and consumption of sugars, a feature coupled to enzymatic activity. In samples grown in beechwood xylan, the reducing sugar concentration after $3 \mathrm{~h}$ ranged from 93 to $61.9 \mu \mathrm{g} / \mathrm{mL}$, with no reducing sugar accumulation during the remaining fermentation time (Figure 2D), when a constant 
concentration of $60 \mu \mathrm{g} / \mathrm{mL}$ was reached. A higher hydrolysis rate was observed in samples grown in nejayote arabinoxylan fermentation in which the carbohydrate concentration increased 3.6-fold, from 123.3 (initial) to $440.2 \mu \mathrm{g} / \mathrm{mL}$, after $4.5 \mathrm{~h}$ of fermentation, indicating a much higher enzymatic activity related to hydrolysis and the production of reducing sugars (Figure 2D). These sugars were consumed until they reached a minimum average concentration of $58.1 \mu \mathrm{g} / \mathrm{mL}$ after $12 \mathrm{~h}$ of culture.

\section{Fermentation Products}

Fermentation products were evaluated by HPLC, with two main chemicals detected: lactic acid and ethanol; acetic acid was detected in negligible concentrations (Figure 3).

The analysis of fermentation supernatants by HPLC revealed that the area of two peaks (retention time 8.4 and $11.6 \mathrm{~min}$, respectively) remained constant from the beginning of the fermentation. Two additional peaks were detected after $4.5 \mathrm{~h}$ of fermentation, not matching any of the monosaccharide standards, and remained until the end of the fermentation (indicated with arrows in Figure 3). The overall trend observed in fermentation products was that metabolite concentrations increased and total carbohydrate concentration decreased as the culture proceeded (Figures 2B, 4).
Based on the fermentation products detected, Sii-25124 metabolizes sugars through heterolactic fermentation via a 6-phosphogluconate (6PG) pathway. This metabolic pathway has been observed in LAB: Enterococcus mundtii QU 25, Lactococcus lactis IO-1, and Lactococcus lactis ssp. lactis IL1403) (Bolotin et al., 2001; Tanaka et al., 2002; Abdel-Rahman et al., 2011a,b). Lactic acid and ethanol were produced in the early stages of fermentation, reaching peak concentrations after $7.5 \mathrm{~h}$ in nejayote arabinoxylan cultures $(24.1 \pm 0.23 \mu \mathrm{mol} / \mathrm{mL}$ ethanol; $23.28 \pm 2.93 \mu \mathrm{mol} / \mathrm{mL}$ lactic acid), and after $9 \mathrm{~h}$ in beechwood xylan cultures $(6.0 \pm 0.75 \mu \mathrm{mol} / \mathrm{mL}$ ethanol; $10.1 \pm 1.22$ $\mu \mathrm{mol} / \mathrm{mL}$ lactic acid), remaining constant until $12 \mathrm{~h}$ in both cases (Figure 4). Ethanol concentration did not increase. Based on the calculation of the theoretical phosphogluconate pathway, one mol of lactate plus one mol of ethanol or acetate were expected per mol of pentose fermented. The ratio remained unchanged up to $12 \mathrm{~h}$. Although homolactic LAB such as streptococci and pediococci use the hexose monophosphate pathway, the 6PG path is followed with pentoses (Kandler, 1983). Additionally, there was a close correlation between reducing carbohydrate consumption and lactic acid production, which further confirmed that the sugars released were being fermented (Figures 2C, 4).

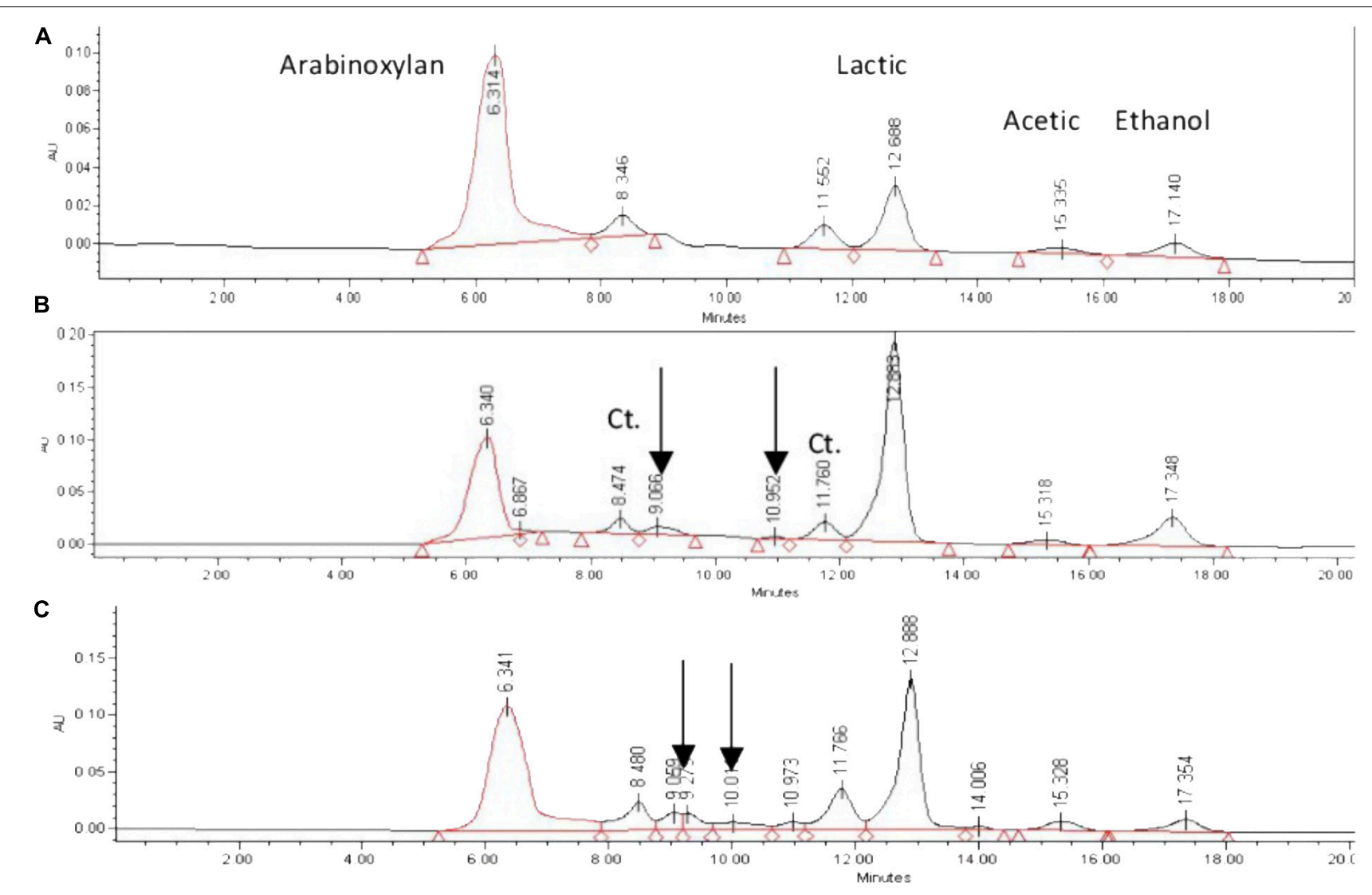

FIGURE 3 | HPLC profiles of fermentation by Streptococcus infantarius ssp. infantarius 25124 in HSH broth spiked with nejayote arabinoxylan as carbon source. Fermentation times: (A) 3 h, (B) 12 h, (C) 30 h. Retention times: arabinoxylan 6.3 min, lactic acid 12.8 min, acetic acid 15.3 min, ethanol 17.3 min. Unknown metabolites shown with arrows. Constant-area peaks indicated with $\mathrm{Ct}$. 


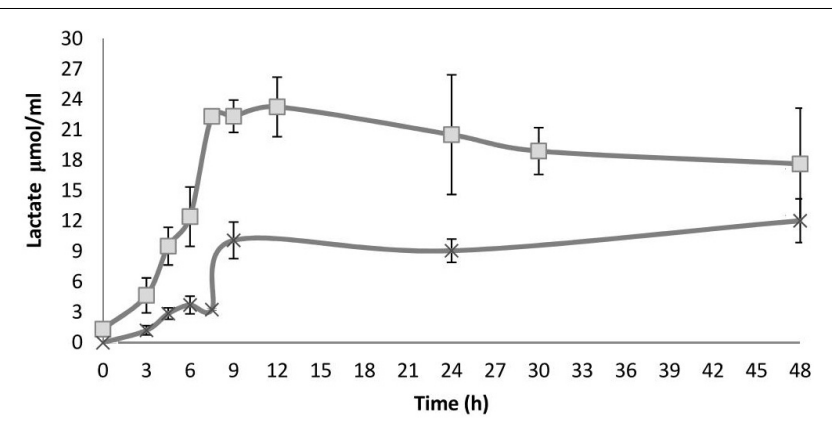

FIGURE 4 | Lactate concentration along fermentation in HSH broth spiked with $1 \%$ beech wood xylan $(X)$ and nejayote arabinoxylan $(\square)$ as the carbon sources and inoculated with S. infantarius ssp. infantarius 25124. Results are means of three independent separate fermentations; standard deviations are shown as vertical lines. There are statistically significant differences between the treatments (nejayote arabinoxylan vs. beechwood xylan).

\section{Evolution of Extracellular Enzymatic Activities \\ Xylanase Activity}

On nejayote arabinoxylan the activity increased almost twofold, with a peak of $135.8 \pm 48.7 \mathrm{IU} / \mathrm{mg}$ protein after $3 \mathrm{~h}$ of fermentation (Figure 2C). Thereafter, the activity decreased gradually and remained constant between 9 and $24 \mathrm{~h}$. The magnitude of xylanase activity was consistent with the amount of reducing sugar produced during fermentation. As the substrate decreased, so did the enzymatic activity and the resulting reducing sugars, reaching a minimum concentration at the end of the fermentation phase (Figure 2D).

However, on beechwood xylan, the peak activity was detected after $6 \mathrm{~h}$ of fermentation, when the activity reached $62.5 \pm 19.8$ $\mathrm{IU} / \mathrm{mg}$ protein; it decreased by only $26 \%$ at the end of the fermentation (Figure 2C).

\section{$\beta$-Xylosidase and Supplementary Xylanase Enzymes}

Supplementary enzymes and $\beta$-xylosidase activity were also assayed. The activity of each of these enzymes was induced separately in the presence of each xylan type, with a more rapid induction found in samples containing nejayote arabinoxylan, except for $\beta$-xylosidase, whose activity was higher in beechwood xylan. This may be explained by the non-branched structure of this arabinoxylan, making growth dependent on the depolymerization of linear xylan. The highest specific activities were detected for $\beta$-arabinosidase, $\beta$-galactosidase, $\beta$-glucosidase, and acetyl xylan esterase (Table 1), in the presence of nejayote arabinoxylan, in which the attached acetyl groups must first be cleaved before endoxylanase can act upon the linear structure from which xylo-oligomers are produced.

High xylanolytic, $\beta$-galactosidase, acetyl-esterase, and $\beta$-xylosidase activities were observed during the initial hours (between 0 and $6 \mathrm{~h}$ ) of the fermentation process in the presence of nejayote arabinoxylan; however, the activity of other supplementary enzymes increased by the end of the fermentation (Table 1). The enzymatic behavior in samples grown in
TABLE 1 | Maximum activities of xylanase supplementary enzymes detected on HSH with nejayote arabinoxylan and beechwood xylan inoculated with Sii-25124 and incubated at $30^{\circ} \mathrm{C}$.

\begin{tabular}{|c|c|c|}
\hline & $\begin{array}{c}\text { Nejayote } \\
\text { arabinoxylan }\end{array}$ & Beechwood xylan \\
\hline$\alpha$-Xylosidase $^{\mathrm{a}}$ & $\begin{array}{c}8.29 \mathrm{lU} / \mathrm{mg} \text { prot } \\
(24 \mathrm{~h})\end{array}$ & $\begin{array}{c}5.71 \mathrm{IU} / \mathrm{mg} \text { prot } \\
(24 \mathrm{~h})\end{array}$ \\
\hline$\beta-X y l o s i d a s e^{a}$ & $\begin{array}{c}3.17 \mathrm{IU} / \mathrm{mg} \text { prot } \\
(4.5 \mathrm{~h})\end{array}$ & $\begin{array}{c}4.43 \mathrm{IU} / \mathrm{mg} \text { prot } \\
(\mathrm{O} \mathrm{h})\end{array}$ \\
\hline$\alpha$-Arabinosidase $\mathrm{e}^{\mathrm{a}}$ & $\begin{array}{c}9.08 \mathrm{IU} / \mathrm{mg} \text { prot } \\
(24 \mathrm{~h})\end{array}$ & $\begin{array}{c}5.15 \mathrm{IU} / \mathrm{mg} \text { prot } \\
(9 \mathrm{~h})\end{array}$ \\
\hline$\beta$-Arabinosidase ${ }^{b}$ & $\begin{array}{c}3.99 \mathrm{IU} / \mathrm{mg} \text { prot } \\
(\mathrm{O} \mathrm{h})\end{array}$ & $\begin{array}{c}5.26 \mathrm{IU} / \mathrm{mg} \text { prot } \\
(6 \mathrm{~h})\end{array}$ \\
\hline$\alpha$-Glucosidase ${ }^{c}$ & $\begin{array}{c}6.65 \mathrm{IU} / \mathrm{mg} \text { prot } \\
(24 \mathrm{~h})\end{array}$ & $\begin{array}{c}5.20 \mathrm{IU} / \mathrm{mg} \text { prot } \\
(9 \mathrm{~h})\end{array}$ \\
\hline$\beta$-Glucosidase ${ }^{a}$ & $\begin{array}{c}8.91 \mathrm{IU} / \mathrm{mg} \text { prot } \\
(24 \mathrm{~h})\end{array}$ & $\begin{array}{c}5.21 \mathrm{IU} / \mathrm{mg} \text { prot } \\
(9 \mathrm{~h})\end{array}$ \\
\hline Acetyl-esterase ${ }^{a}$ & $\begin{array}{c}33.4 \mathrm{IU} / \mathrm{mg} \text { prot } \\
(4.5 \mathrm{~h})\end{array}$ & $\begin{array}{c}9.13 \mathrm{IU} / \mathrm{mg} \text { prot } \\
(24 \mathrm{~h})\end{array}$ \\
\hline$\alpha$-Galactosidase $\mathrm{a}^{\mathrm{a}}$ & $\begin{array}{c}5.35 \mathrm{IU} / \mathrm{mg} \text { prot } \\
(\mathrm{O} \mathrm{h})\end{array}$ & $\begin{array}{l}4.46 \mathrm{IU} / \mathrm{mg} \text { prot } \\
(4.5 \mathrm{~h})\end{array}$ \\
\hline$\beta$-Galactosidase ${ }^{a}$ & $\begin{array}{c}6.72 \mathrm{IU} / \mathrm{mg} \text { prot } \\
(6 \mathrm{~h})\end{array}$ & $\begin{array}{c}4.18 \mathrm{IU} / \mathrm{mg} \text { prot } \\
(\mathrm{O} \mathrm{h})\end{array}$ \\
\hline
\end{tabular}

Incubation times in parenthesis. $U$, $\mu \mathrm{mol}$ of liberated PNP/min*mL. ${ }^{a}$ There were statistical differences along fermentation time between treatments (nejayote arabinoxylan vs. beechwood xylan). ${ }^{b}$ There was statistical difference between treatments on 3, 6, and $24 \mathrm{~h} .{ }^{c}$ There was statistical difference between treatments except on 9th hour $(\alpha=0.01)$.

beechwood xylan differed, as some of the supplementary enzymes reached a peak activity at $9 \mathrm{~h}$ of fermentation, when the peak lactate concentration was observed (Figure 4). Alfaxylosidase and acetyl-esterase activities peaked at $24 \mathrm{~h}$, toward the end of the fermentation.

\section{DISCUSSION}

The outer layers of maize kernels must be pretreated to make them accessible to cellulolytic and xylanolytic enzymes during fermentation. This pretreatment step is a bottleneck in their consumption by microorganisms and in the bio-processing of lignocellulosic materials for the production of biofuel, prebiotics or any other biological products (Alonso et al., 2001). To address this biological barrier and foster fermentation, either enzymatic hydrolysis by cellulases and hemicellulases (xylanases and supplementary enzymes) or chemical or physical hydrolysis is required.

An example of this process is maize nixtamalization. This has been used by Mesoamerican indigenous populations since Pre-Columbian times. This heat-alkali pretreatment causes discontinuity in the lignin structure by cleaving the bonds between lignin and carbohydrates, and removing acetyl and other acid groups, hence making them accessible to enzymes (Agbor et al., 2011). Overall, arabinoxylan is the second largest fermentable source of carbohydrates, only after starch $(71.7 \%$ starch and $6.2 \%$ hemicellulose in the whole maize kernel (Watson and Ramstad, 1987). The thermal treatment also solubilizes arabinoxylan; therefore, this chemical is found in 
the resulting nixtamal dough, hence increasing the availability of carbon sources for microbial growth, as well as in the wash water (nejayote). Because of this enhanced bioavailability, the consumption of arabinoxylan in the dough by xylanolytic LAB strains may proceed via arabinoxylan hydrolysis, a process releasing sugars that become available for fermentation.

To prove this hypothesis, arabinoxylan was extracted from nejayote and used as the sole carbon source in $\mathrm{HSH}$ defined medium. Growth, total and reducing carbohydrate content, and lactic and ethanol production were measured; Streptococcus infantarius ssp. infantarius 25124 (Sii-25124) underwent vigorous growth in the presence of arabinoxylan. This strain, which predominates during pozol fermentation, is homofermentative, but follows the 6PG pathway when it consumes pentoses. This work revealed that this microorganism was able to grow by hydrolyzing arabinoxylan.

Our results demonstrate that Sii-25124 was able to grow in the presence of arabinoxylan, inducing enzymatic activities that are needed for extracellular hydrolysis to facilitate fermentation. The high acetyl-esterase activity observed at the beginning of nejayote fermentation shows the adaptation of this strain to nixtamal dough arabinoxylans, as growth in a different xylan source, i.e., beech wood xylan, resulted in less efficient hydrolysis and carbohydrate fermentation. The high standard deviation values obtained for nejayote arabinoxylan are attributed to the heterogeneous nature of this substrate.

Xylanase activity was directly related to the growth of Sii25124. As its activity in the presence of nejayote arabinoxylan became constant (from $9 \mathrm{~h}$ onward), the culture entered the death phase. This result contrasts with xylanase activity in beechwood xylan, which remained constant up to $24 \mathrm{~h}$.

However, catabolic repression may inhibit Sii-25124 xylanase. In samples grown in beechwood xylan, total sugar consumption was slow, allowing the culture to continue growing and xylanase activity to remain constant throughout fermentation, with minimum lactate accumulation; when grown in nejayote arabinoxylan, it showed high xylanase activity that produced reducing carbohydrates and supplementary enzymes. Reducing sugars were quickly depleted, lactate and ethanol concentrations increased, and then xylanase activity decreased to a minimum value, while some of the supplementary enzymes reached a peak activity at $24 \mathrm{~h}$ (Table 1). This would allow Sii-25124 to utilize the different sugars produced and grow; the culture, however, started to decline.

This finding suggests that the differences observed in growth and enzyme production with xylan and arabinoxylan arise from their structural characteristics, but also point to that Sii-25124 possesses the ability to adapt to an hemicellulolytic environment. Hence, the prevalence of pozol fermentation by this strain may be based on its adaptive ability to utilize several complex carbon sources.

Lactic acid bacterium have been found in bioconversion reactions involving the transformation of hemicellulose fractions to lactic acid, mainly in genetically modified strains. Hu et al. (2011) achieved the direct conversion of xylan to lactic acid using a Lactobacillus brevis strain transformed with a xylanase gene. To allow a one-step hydrolysis and fermentation of lignocellulosic substrates, Moraïs et al. (2013) employed a $L b$. plantarum strain engineered with genes coding for a GH6 cellulase and a GH11 xylanase to produce the respective enzymes, which worked synergistically. Xylanases are also involved in the production of XOs and arabinooligosaccharides (AXOs) that, according to Grootaert et al. (2007), have potential beneficial effects in humans as prebiotics and soluble dietary fiber (AzevedoCarvalho et al., 2013). It is commonly accepted that diet has a major influence on the gut microbial community, Rivière et al. (2016) and $\mathrm{Li}$ et al. (2017) reported that consuming foods that contain prebiotics such as inulin-type fructans (ITF) xylan and arabinoxylan oligosaccharides (AXOs), favored the growth of Bacteroides and of bifidobacteria in colon, contributing to human physiological functions and health. Bifidobacterium spp., one the most important probiotic groups of gut bacteria, grow in the presence of XOs and AXOs as carbon sources that facilitate the prebiotic functions of these bacteria (Wang et al., 2010; Amaretti et al., 2013) which include production of antioxidants, vitamin $\mathrm{B}$, conjugated linolenic acids, protection against pathogens and stimulation of the immune system; AX and AXOs have also shown to cause a butyrogenic effect (Rivière et al., 2016).

Some Sii strains have been associated with traditional African dairy and plant-based fermented foods, so these should be compared with the Sii-25124 strain isolated from pozol. Sii-25124 is capable of growing in the presence of starch and sucrose, among other carbohydrates, as concluded from API 50CH (Díaz-Ruiz et al., 2003). It is important to stress that although Lactobacillus are the predominant strains in fermented doughs, such as sourdoughs, and nonnixtamalized fermented maize foods (Corsetti and Settani, 2007; De Vuyst et al., 2009; Iacumin et al., 2009), the pozol microbiota is markedly different. This may be the result of the nixtamalization process, which could act as a selective force of some strains.

\section{CONCLUSION}

We have shown that Streptococcus infantarius ssp. infantarius 25124 (Sii-25124) grows in cultures added with arabinoxylan from nejayote, besides being the most ALAB in pozol, displaying its ability to prevail in the fermentation of this dough. Xylanase and supplementary enzymes were produced when exposed to xylan; $\beta$-arabinosidase, $\beta$-galactosidase, $\beta$-glucosidase, and acetyl xylan esterase were the most active enzymes. These results show that besides starch, xylan and arabinoxylan serve as substrates for lactic acid bacteria fermentation of pozol dough.

\section{AUTHOR CONTRIBUTIONS}

CW is the tutor of the student, she supervised the experimental procedures and the writing of the manuscript. BC-B was responsible for the experimental procedures and the writing of the article. AN-O, RR-S, GD-R, and GA-O undertook some of the experiments and reviewed the manuscript. 


\section{FUNDING}

This work was supported by CONACYT, Mexico, Project CB2013-131615 and by PAPIIT/UNAM Mexico, Project IN223917 and BC-B thanks to CONACYT for grant 203632.

\section{REFERENCES}

Abdel-Rahman, M. A., Tashiro, Y., and Sonomoto, K. (2011a). Lactic acid production from lignocellulose-derived sugars using lactic acid bacteria: overview and limits. J. Biotechnol. 156, 286-301. doi: 10.1016/j.jbiotec.2011. 06.017

Abdel-Rahman, M. A., Tashiro, Y., Zendo, T., Hanada, K., Shibata, K., and Sonomoto, K. (2011b). Efficient homofermentative L-(+)-lactic acid production from Xylose by a novel lactic acid bacterium, Enterococcus mundtii QU 25. Appl. Environ. Microbiol. 77, 1892-1895. doi: 10.1128/AEM. 02076-10

Agbor, V. B., Cicek, N., Sparling, R., Berlin, A., and Levin, D. B. (2011). Biomass pretreatment: fundamentals toward application. Biotechnol. Adv. 29, 675-685. doi: 10.1016/j.biotechadv.2011.05.005

Alonso, J. L., Dominguez, H., Garrote, G., Gonzalez-Munoz, M. J., Gullon, B., Moure, A., et al. (2001). Biorefinery processes for the integral valorization of agroindustrial and forestal wastes. CyTA J. Food 9, 282-289. doi: 10.1080/ 19476337.2011.598949

Amaretti, A., Bernardi, T., Leonardi, A., Raimondi, S., Zanoni, S., and Rossi, M. (2013). Fermentation of xylo-oligosaccharides by Bifidobacterium adolescentis DSMZ 18350: kinetics, metabolism, and $\beta$-xylosidase activities. Appl. Microbiol. Biotechnol. 97, 3109-3117. doi: 10.1007/s00253-012-4509-y

Ampe, F., Ben Omar, N., Moizan, C., Wacher, C., and Guyot, J. P. (1999). Polyphasic study of the spatial distribution of microorganisms in Mexican pozol, a fermented maize dough, demonstrates the need for cultivationindependent methods to investigate traditional fermentations. Appl. Environ. Microbiol. 65, 5464-5473.

Azevedo-Carvalho, A. F., de Oliva-Neto, P., Fernandes da Silva, D., and Pastore, G. M. (2013). Xylo-oligosaccharides from lignocellulosic materials: chemical structure, health benefits and production by chemical and enzymatic hydrolysis. Food Res. Int. 51, 75-85. doi: 10.1016/j.foodres.2012.11.021

Bailey, M. J., Biely, P., and Poutanen, K. (1992). Interlaboratory testing methods for assay of xylanase activity. J. Biotechnol. 23, 257-270. doi: 10.1016/01681656(92)90074-J

Baty, F., and Delignette-Muller, L. B. (2004). Estimating the bacterial lag time: which model, which precision? Int. J. Food Microbiol. 91, 261-277. doi: 10.1016/ j.ijfoodmicro.2003.07.002

Ben Omar, N., and Ampe, F. (2000). Microbial community dynamics during production of the Mexican fermented maize dough pozol. Appl. Environ. Microbiol. 66, 3664-3673. doi: 10.1128/AEM.66.9.3664-3673.2000

Bolotin, A., Wincker, P., Mauger, S., Jaillon, O., Malarme, K., Weissenbach, J., et al. (2001). The complete genome sequence of the lactic acid bacterium Lactococcus lactis ssp. lactis IL1403. Genome Res. 11, 731-753. doi: 10.1101/gr.GR-1697R

Bradford, M. M. (1976). A rapid and sensitive method for the quantitation of microgram quantities of protein utilizing the principle of protein-dye binding. Anal. Biochem. 72, 248-254. doi: 10.1016/0003-2697(76)90527-3

Cañas, A. O., Bárzana, E., Owens, J. D., and Wacher, C. (1993). La elaboración de pozol en los altos de Chiapas. Ciencia 44, 219-229.

Carvajal-Millan, E., Rascón-Chu, A., Márquez-Escalante, J. A., Micard, V., Ponce de León, N., and Gardea, A. (2007). Maize bran gum: extraction, characterization and functional properties. Carbohydr. Polym. 69, 280-285. doi: $10.1016 /$ j.carbpol.2006.10.006

Corsetti, A., and Settani, L. (2007). Lactobacilli in sourdough fermentation. Food Res. Int. 2007, 539-558. doi: 10.1016/j.foodres.2006.11.001

De Vuyst, L., Vrancken, G., Ravyts, F., Rimaux, T., and Weckx, S. (2009). Biodiversity, ecological determinants, and metabolic exploitation of sourdough microbiota. Food Microbiol. 26, 666-675. doi: 10.1016/j.fm.2009.07.012

Díaz-Ruiz, G., Guyot, J. P., Ruiz-Teran, F., Morlon-Guyot, J., and Wacher, C. (2003). Microbial and physiological characterization of weakly amylolytic but fast-growing lactic acid bacteria: a functional role in supporting microbial

\section{ACKNOWLEDGMENTS}

We are grateful to Alberto Tecante Coronel, Hilda Calderón V., and Ma. Teresa Flores-Espinosa for technical assistance and María Elena Sánchez-Salazar who edited the English manuscript.

diversity in pozol, a Mexican fermented maize beverage. Appl. Environ. Microbiol. 69, 4367-4374. doi: 10.1128/AEM.69.8.4367-4374.2003

Dubois, M., Gilles, A., Hamilton, J. K., Rebers, P. A., and Smith, F. (1956). Colorimetric method for determination of sugars and related substances. Anal. Chem. 128, 350-356. doi: 10.1021/ac60111a017

Englyst, H. N., and Hudson, G. J. (1996). The classification and measurement of dietary carbohydrates. Food Chem. 57, 15-21. doi: 10.1016/0308-8146(96) 00056-8

Erlandson, K. A., Delamarre, C., and Batt, C. A. (2001). Genetic evidence for a defective Xylan degradation pathway in Lactococcus lactis. Appl. Environ. Microbiol. 67, 1445-1452. doi: 10.1128/AEM.67.4.1445-1452.2001

Escalante, A., Wacher, C., and Farres, A. (2001). Lactic acid bacterial diversity in the traditional Mexican fermented dough pozol as determined by $16 \mathrm{~S}$ rDNA sequence analysis. Int. J. Food Microbiol. 64, 21-31. doi: 10.1016/S01681605(00)00428-1

Grootaert, C., Delcour, J. A., Courtin, C. M., Broekaert, W. F., Verstraete, W., and Van de Wiele, T. (2007). Microbial metabolism and prebiotic potency of arabinoxylan oligosaccharides in the human intestine. Trends Food Sci. Technol. 18, 64-71. doi: 10.1016/j.tifs.2006.08.004

Hu, C. Y., Chi, D. J., Chen, S. S., and Chen, Y. C. (2011). The direct conversion of xylan to lactic acid by Lactobacillus brevis transformed with a xylanase gene. Green Chem. 13, 1729-1734. doi: 10.1039/c1gc15169j

Iacumin, L., Cecchini, F., Manzano, M., Osualdini, M., Boscolo, D., Orlic, S., et al. (2009). Description of the microflora of sourdoughs by culture-dependent and culture-independent methods. Food Microbiol. 26, 128-135. doi: 10.1016/j.fm. 2008.10.010

Instituto Nacional de Nutrición Salvador Zubirán [INNSZ] (1996). Tablas de Composición de Alimentos del INNSZ. Mexico: INNSZ.

Jans, C., and Bolieij, A. (2018). The road to infection: host-microbe interactions defining the pathogenicity of Streptococcus bovis/Streptococcus equinus complex members. Front. Microbiol. 9:603. doi: 10.3389/fmicb.2018.00603

Jans, C., Meile, L., Kaindi, D. W. M., Kogi-Makau, W., Lamuka, P., Renault, P., et al. (2017). African fermented dairy products - overview of predominant technologically important microorganisms focusing on African Streptococcus infantarius variants and potential future applications enhanced food safety and security. Int. J. Food Microbiol. 250, 27-36. doi: 10.1016/j.ijfoodmicro.2017. 03.012

Kaindi, D. W. M., Kogi-Makau, W., Lule, G. N., Kreikemeyer, B., Renault, P., Bonfoh, B., et al. (2018). Colorectal cancer-associated Streptococcus infantarius subsp.infantarius differ from a major dairy lineage providing evidence for pathogenic, pathobiont and food-grade lineages. Sci. Rep. 8:9181. doi: 10.1038/ s41598-018-27383-4

Kandler, O. (1983). Carbohydrate metabolism in lactic acid bacteria. Antonie Van Leeuwenhoek 49, 209-224. doi: 10.1007/BF00399499

Li, J., Hou, Q., Zhang, J., Xu, H., Sun, Z., Menghe, B., et al. (2017). Carbohydrate staple food modulates gut microbiota of Mongolians in China. Front. Microbiol. 8:484. doi: $10.3389 /$ fmicb.2017.00484

Madhukumar, M. S., and Muralikrishna, G. (2012). Fermentation of xylooligosaccharides obtained from wheat bran and Bengal gram husk by lactic acid bacteria and bifidobacteria. J. Food Sci. Technol. 49, 745-752. doi: 10.1007/ s13197-010-0226-7

Miller, G. L. (1959). Use of dinitrosalicylic acid reagent for determination of reducing sugar. Anal. Chem. 31, 426-428. doi: 10.1021/ac60147a030

Moraïs, S., Shterzer, N., Rozman, I., Mathiesen, G., Eijsink, V., Axelsson, L., et al. (2013). Establishment of a simple Lactobacillus plantarum cell consortium for cellulase-xylanase synergistic interactions. Appl. Environ. Microbiol. 79, 5242-5249. doi: 10.1128/AEM.01211-13

Nuraida, L., Grigolava, I., Owens, J. D., and Campbell-Platt, G. (1992). Oxygen and pyruvate as external electron acceptors for Leuconostoc spp. J. Appl. Bacteriol. 72, 517-522. doi: 10.1111/j.1365-2672.1992.tb01869.x 
Oliveira, E. E., Silva, A., Nagashima, T., Salgado, M., Muratori, L., Rodrigues, H., et al. (2010). Xylan from corn cobs, a promising polymer for drug delivery: production and characterization. Bioresour. Technol. 101, 5402-5406. doi: 10. 1016/j.biortech.2010.01.137

Owens, J. D., and Keddie, R. M. (1969). The nitrogen nutrition of soil and herbage coryneform bacteria. J. Appl. Bacteriol. 32, 338-347. doi: 10.1111/j.1365-2672. 1969.tb00981.x

Papadimitriou, K., Anastasiou, R., Mavrogonatou, R., Blom, J., Papandreou, C., Hamodrakas, S. J., et al. (2014). Comparative genomics of the dairy isolate Streptococcus macedonicus ACA-DC 198 against related members of the Streptococcus bovis/Streptococcus equinus complex. BMC Genomics 15:272. doi: 10.1186/1471-2164-15-272

Pérez-Avalos, O., Ponce-Noyola, T., Magaña-Plaza, I., and De la Torre, M. (1996). Induction of xylanase and $\beta$-xylosidase in Cellulomonas flavigena growing on different carbon sources. Appl. Microbiol. Biotechnol. 46, 405-409. doi: 10.1007/ BF00166237

Poyart, C., Quesne, G., and Trieu-Cuot, P. (2002). Taxonomic dissection of the Streptococcus bovis group by analysis of manganese-dependent superoxide dismutase gene (sodA) sequences: reclassification of 'Streptococcus infantarius subsp. coli' as Streptococcus lutetiensis sp. nov. and of Streptococcus bovis biotype II.2 as Streptococcus pasteurianus sp. nov. Int. J. Syst. Evol. Microbiol. 52, 1247-1255.

Rickard, P. A. D., and Laughlin, T. A. (1980). Detection and assay of xylanolytic enzymes in a Cellulomonas isolate. Biotechnol. Lett. 2, 363-368. doi: 10.1007/ BF00138670

Rivière, A., Selak, M., Lantin, D., Leroy, F., and De Vuyst, L. (2016). Bifidobacteria and butyrate-producing colon bacteria: importance and strategies for their stimulation in the human gut. Front. Microbiol. 7:979. doi: 10.3389/fmicb.2016. 00979

Romero, B., Morosini, M.-I., Loza, E., Rodríguez-Baños, M., Navas, E., Cantón, R., et al. (2011). Reidentification of Streptococcus bovis isolates causing bacteremia according to the new taxonomy criteria: still an issue? J. Clin. Microbiol. 49, 3228-3233. doi: 10.1128/JCM.00524-11

Sanchez-Castillo, C. P., Englyst, H. N., Hudson, G. J., Lara, J. J., de Lourdes Solano, M., Munguía, J. L., et al. (1999). The non-starch polysaccharide content of Mexican foods. J. Food Compost. Anal. 12, 293-314. doi: 10.1006/jfca.1999. 0831

Santillana, R. (1995). Desarrollo de un Método Por Cromatografía Líquida de Alta Eficiencia Para el Análisis Químico de Nixtamal y Pozol. Master thesis, Universidad Nacional Autónoma de México, Ciudad de Mexico.

Schlegel, L., Grimont, F., Ageron, E., Grimont, P. A. D., and Bouvet, A. (2003). Reappraisal of the taxonomy of Streptococcus bovis/Streptococcus equinus complex and related species: description of Streptococcus gallolyticus subsp. gallolyticus subsp. nov., Streptococcus gallolyticus subsp. macedonicus subsp. nov., comb. nov. and Streptococcus gallolyticus subsp. septicus subsp. nov. Int. J. Syst. Evol. Microbiol. 53, 631-645. doi: 10.1099/ijs.0. 02361-0

Schlegel, L., Grimont, F., Collins, M. D., Régnault, B., Grimont, P. A. D., and Bouvet, A. (2000). Streptococcus infantarius sp. nov., Streptococcus infantarius subsp. infantarius subsp. nov. and Streptococcus infantarius subsp. coli subsp. nov., isolated from humans and food. Int. J. Syst. Evol. Microbiol. 50(Pt 4), 1425-1434.

Tanaka, K., Komiyama, A., Sonomoto, K., Ishizaki, A., Hall, S. J., and Stanbury, P. F. (2002). Two different pathways for D-xylose metabolism and the effect of xylose concentration on the yield coefficient of L-lactate in mixed-acidfermentation by the lactic acid bacterium Lactococcus lactis IO-1. Appl. Microbiol. Biotechnol. 60, 160-167. doi: 10.1007/s00253-002-1078-5

Ulloa, M., Herrera, T., and Lappe, P. (1987). Fermentaciones Tradicionales Indígenas de México. México: Instituto Nacional Indigenista.

Uniprot (2015). The Universal Protein Resource. Available at: http://www. uniprot.org

Wang, J., Sun, B., Cao, Y., and Wang, C. (2010). In vitro fermentation of xylooligosaccharides from wheat bran insoluble dietary fiber by Bifidobacteria. Carbohydr. Polym. 82, 419-423. doi: 10.1016/j.carbpol.2010.04.082

Watson, S., and Ramstad, P. (1987). "Structure and composition," in Corn :Chemistry and Technology, eds S. A. Watson and P. E. Ramstad (St. Paul, MN: American Association of Cereal Chemists), 53-83.

Westby, A., Nuraida, L., Owens, J. D., and Gibbs, P. A. (1993). Inability of Lactobacillus plantarum and other lactic acid bacteria to grow on D-ribose as sole source of fermentable carbohydrate. J. Appl. Bacteriol. 75, 168-175. doi: 10.1111/j.1365-2672.1993.tb02763.x

Zaunmüller, T., Eichert, M., Richter, H., and Unden, G. (2006). Variations in the energy metabolism of biotechnologically relevant heterofermentative lactic acid bacteria during growth on sugars and organic acids. Appl. Microbiol. Biotechnol. 72, 421-429. doi: 10.1007/s00253-006-0514-3

Zwietering, M. H., Jongenburger, I., Rombouts, F. M., and Van 't Riet, K. (1990). Modeling of the bacterial growth curve. Appl. Environ. Microbiol. 56, 18751881.

Conflict of Interest Statement: The authors declare that the research was conducted in the absence of any commercial or financial relationships that could be construed as a potential conflict of interest.

Copyright (c) 2018 Cooper-Bribiesca, Navarro-Ocaña, Díaz-Ruiz, Aguilar-Osorio, Rodríguez-Sanoja and Wacher. This is an open-access article distributed under the terms of the Creative Commons Attribution License (CC BY). The use, distribution or reproduction in other forums is permitted, provided the original author(s) and the copyright owner(s) are credited and that the original publication in this journal is cited, in accordance with accepted academic practice. No use, distribution or reproduction is permitted which does not comply with these terms. 